J. Dairy Sci. 99:8499-8510

http://dx.doi.org/10.3168/jds.2015-10626

(C) American Dairy Science Association ${ }^{\circledR}, 2016$.

\title{
Antioxidant activity of milk protein hydrolysate in alloxan-induced diabetic rats
}

\author{
S. Awad, ${ }^{* 1}$ M. I. El-Sayed, ${ }^{*} \dagger$ A. Wahba, ${ }^{*}$ A. El Attar, ${ }^{*}$ M. I. Yousef, $\ddagger$ and M. Zedan† \\ *Department of Dairy Science and Technology, Faculty of Agriculture, Alexandria University, Alexandria 21545, Egypt \\ †Department of Dairy Technology Research, Food Technology Research Institute, ARC, Giza 12622, Egypt \\ ‡Department of Environmental Studies, Institute of Graduate Studies and Research, Alexandria University, Alexandria 21526, Egypt
}

\section{ABSTRACT}

We investigated the effects of milk protein concentrate (MPC) and milk protein concentrate hydrolysate $(\mathrm{MPCH})$ as antioxidant agents in rats. Six groups of healthy (non-diabetic) and type-II diabetic rats were used: (1) healthy rats (control), (2) alloxan-induced rats (diabetic control group), (3) healthy rats treated orally with MPC, (4) diabetic rats treated orally with MPC, (5) healthy rats treated orally with MPCH, and (6) diabetic rats treated orally with $\mathrm{MPCH}$. We concluded that treatment with MPC or MPCH reduced the level of thiobarbituric acid reactive substances in healthy and diabetic rats. Treatment with MPC or MPCH improved activities of antioxidant enzymes (catalase, superoxide dismutase, reduced glutathione, glutathione-S-transferase, and glutathione peroxidase) in healthy and diabetic rats. From the present data, we concluded that both MPC and MPCH contain potent antioxidants and could improve the health of rats or other animals with diabetes mellitus.

Key words: bioactive peptide, type-2 diabetes, free radical, antioxidant enzyme

\section{INTRODUCTION}

Bovine milk is an excellent source of proteins of high biological value; it is characterized by a complete AA profile and high digestibility. Apart from their nutritional value, milk proteins and peptides have a wide range of biological functions (Szwajkowska et al., 2011). Milk proteins are among the most important sources of bioactive peptides; these remain inactive within the sequence of the parent protein until they are released either by gastrointestinal digestion or by food

Received November 11, 2015.

Accepted July 15, 2016.

${ }^{1}$ Corresponding author: sameh111eg@yahoo.com processing. Bioactive peptides are specific protein fragments that have a positive effect on body functions or conditions and may ultimately influence health (Kitts and Weiler, 2003). Their beneficial health effects are classified as antimicrobial, immunomodulatory, bloodpressure lowering, antithrombotic, antioxidant (AO), and opioid-like, in addition to lowering cholesterol and enhancing mineral absorption and bioavailability (Plaisancié et al., 2013).

The in vivo release of bioactive peptides from milk proteins in the gastrointestinal tract results from the action of digestive enzymes such as pepsin and pancreatic enzymes. The efficiency of the physiological activity of biopeptides depends on their ability to maintain an integral state during transport to the various functional systems of the body (Vermeirssen et al., 2004; Picariello et al., 2010). Also, studies have indicated that bioactive peptides encrypted in major milk proteins are latent within the sequence of the parent protein molecule. They can be liberated by (1) gastrointestinal digestion of milk, (2) fermentation of milk with proteolytic starter cultures, or (3) hydrolysis by proteolytic enzymes. In relation to their mode of action, bioactive peptides may reach target sites at the luminal side of the intestinal tract or, after absorption, in peripheral organs (Kamau et al., 2010).

Most studies have shown that many of the known bioactive peptides are produced using gastrointestinal enzymes, usually pepsin and trypsin. Angiotensinconverting enzyme inhibitory peptides and calciumbinding phosphopeptides (CPP), for example, are most commonly produced by trypsin (Meisel and FitzGerald, 2003; FitzGerald et al., 2004; Gobbetti et al., 2004; Korhonen and Pihlanto, 2006). Peptides generated from the digestion of various proteins are reported to have antioxidative activities. Studies with peptides containing histidine have demonstrated that these peptides can act as metal-ion chelators, active-oxygen quenchers, and hydroxyl radical scavengers. The ability of protein hydrolysates to inhibit deleterious changes caused by lipid oxidation appears to be related to the nature and 
composition of the different peptide fractions produced, depending on the protease specificity (Pihlanto, 2006).

Antioxidative peptides from foods are considered safe and healthy compounds of low molecular weight, with 5 to $16 \mathrm{AA}$ residues; they are low cost, have high activity, and are easily absorbed. They have some advantages over enzymatic antioxidants: because of their simpler structure, they are more stable in different situations and do not induce hazardous immunoreactions (Sarmadi and Ismail, 2010). Peptides generated from the digestion of milk proteins are reported to have AO activity. These peptides are usually 5 to 11 AA, including hydrophobic AA, proline, histidine, tyrosine, or tryptophan (Kamau et al., 2010).

Caseins have been shown to provide antioxidant activity against thiobarbituric acid-reactive substance (TBARS) content in Fe- or ascorbate-induced peroxidation of arachidonic-derived liposomes and model linoleic acid systems (Pihlanto, 2006). Casein phosphopeptides are reported to have $\mathrm{AO}$ activity; CPP are derived from enzymatic hydrolysis of casein and are rich in phosphoserine residues. The proposed mechanism for the AO activity of CPP is linked to the presence of phosphate groups originating from the phosphoserine residues close to the peptide chain. This creates a polar and anionic domain that can sequester cationic metal ions. Casein phosphopeptides contain the functional domain SerP-SerP-SerP-Glu-Glu and have been shown to possess 2,2'-azino-bis(3-ethylbenzthiazoline-6-sulfonic acid)-radical scavenging and hydroxyl, peroxyl, and metal chelating activity (Kitts, 2005; Kim et al., 2007).

Phelan et al. (2009) found that casein hydrolysates affected both cellular catalase (CAT) activity and glutathione (GSH) content in Jurkat cells. In addition, they found that casein hydrolysates contained a degree of electron-donating capacity as determined by the ferric-reducing antioxidant power (FRAP) assay (17-32 mmol L ${ }^{-1}$ ). Pritchard et al. (2010) found that bioactive peptides in commercial Cheddar cheese showed the highest inhibition of 2,2-diphenyl-1-picrylhydrazyl (DPPH). The results indicate that the higher the concentration of peptide, the higher the inhibition of DPPH. Hydrolysates of whey protein isolate have been shown to possess AO activity. Five-hour digestion with alcalase produced a hydrolysate with strong reducing power (FRAP). When fractionated based on molecular mass, the low-molecular-weight fraction $(0.1-2.8 \mathrm{kDa})$ was most potent (Peng et al., 2009).

The AO activity of whey protein concentrate (WPC) has been attributed to its Cys content and the ability to elevate cellular GSH (Gad et al., 2011). Therefore, the purpose of the present study was to assess the AO activity of milk protein hydrolysate in healthy and diabetic rats.

\section{MATERIALS AND METHODS}

Cow milk protein concentrate was obtained from Fonterra Ltd. (Auckland, New Zealand); its analysis according to the producer was $69.89 \%$ protein, $17 \%$ lactose, $1.4 \%$ milk fat, $7.2 \%$ minerals, and $4.6 \%$ moisture. Other chemicals were obtained as follows: trypsin 2,000 U/g (EX pancrease) was obtained from Loba Chemie (Mumbai, India). Alloxan was obtained from Alpha Co. (Mumbai, India) and was dissolved in saline solution $(0.9 \% \mathrm{NaCl}, \mathrm{pH} 7)$. The dose of alloxan $(120 \mathrm{mg} / \mathrm{kg}$ of BW per day) was chosen to induce diabetes in rats according to Mansour et al. (2002) and Sheweita et al. (2002). Acetonitrile (HPLC grade) was from Scharlau, (Barcelona, Spain). Trifluoroacetic acid (HPLC grade) was from SDS (Peypin, France). The HPLC peptide standard mixture (product No. H 2016) was obtained from Sigma-Aldrich (St. Louis, MO).

\section{Preparation of Milk Protein Hydrolysates}

Preparation of milk protein hydrolysate was carried out according to the method of Otte et al. (2007). Protein solutions ( $2 \% \mathrm{wt} / \mathrm{wt}$ on a protein basis) were made by dispersing approximately $2.85 \mathrm{~g}$ of milk protein concentrate (according to the protein content) in $97.15 \mathrm{~mL}$ of distilled water to a final weight of $100 \mathrm{~g}$, and stirring for $1 \mathrm{~h}$ at room temperature. Solutions were hydrated overnight at $5^{\circ} \mathrm{C}$; then, the $\mathrm{pH}$ was adjusted to 6.8 or 7.5 using $1 \%$ (wt/vol) $\mathrm{NaOH}$ solution. Trypsin solution $\left(3.2 \mathrm{U} \mathrm{mL}^{-1}\right)$ was prepared in distilled water immediately before use. The hydrolysis process was started by addition of trypsin at a concentration of enzyme (units) to substrate (protein) of 80:100 (2×), 160:100 $(4 \times)$, and 320:100 $(8 \times)$, and then $1 \mathrm{~mL}$ was withdrawn as control sample at zero time. The reaction mixture was incubated at $40^{\circ} \mathrm{C}$, and interval samples $(1 \mathrm{~mL})$ were withdrawn after $3,6,9,20$, and $24 \mathrm{~h}$ of hydrolysis. The enzyme was inactivated by heating at $90^{\circ} \mathrm{C}$ for 15 min, and was then cooled for 20 min in ice bath and centrifuged (Sigma centrifuge 113, VWR International, Darmstadt, Germany) for $10 \mathrm{~min}$ at $10,000 \times g$ and $4^{\circ} \mathrm{C}$. The supernatant was used for further analyses by reverse-phase (RP) HPLC.

\section{Analysis of Peptides by RP-HPLC}

Separation of the peptide extracts was carried out using an HPLC system (Agilent Technologies 1260, Santa Clara, CA) according to the method described by Awad et al.(1998). Solvent A was 0.1\% (vol/vol) trifluoroacetic acid in water, and solvent $\mathrm{B}$ was $0.1 \%$ (vol/vol) trifluoroacetic acid in acetonitrile. A Merck WP 300 RP-18 HPLC column $(5 \mu \mathrm{m}, 250 \times 4.6 \mathrm{~mm}$; 
Merck, Kenilworth, NJ) was used for analyses. Samples were filtered through a $0.2-\mu \mathrm{m}$ membrane filter (Millipore Corp., Bedford, MA). Fifty microliters of $3 \%$ (wt/ vol) peptide extract was injected into the column. The sample was eluted with a 4-step linear gradient over a period of $75 \mathrm{~min}$, at a flow rate of $1.0 \mathrm{~mL} / \mathrm{min}$. The linear gradient started with solvent A for $5 \mathrm{~min}$, then increased linearly from 0 to $50 \%$ ( $\mathrm{vol} / \mathrm{vol}$ ) solvent B for $60 \mathrm{~min}$, followed by $50 \%$ solvent $\mathrm{B}$ for $5 \mathrm{~min}$, and by a linear gradient from 50 to $100 \%$ solvent B over 5 min to clean the column. Before the next injection, the column was allowed to equilibrate with solvent A for $15 \mathrm{~min}$. Separation was conducted at $30^{\circ} \mathrm{C}$ and peptides were monitored at 200 and $230 \mathrm{~nm}$.

\section{Animals and Treatments}

Sixty healthy male albino rats $(\sim 190-200 \mathrm{~g})$ were obtained from the Institute of Graduate Studies and Research, Alexandria University, Egypt. The animals were housed in cages under proper environmental conditions. Animals were housed 5 per cage and fed a commercial diet. Rats were fed pellets consisting of $30 \%$ berseem (Trifolium alexandrinum) hay, $25 \%$ yellow corn, $26.2 \%$ wheat bran, $14 \%$ soybean meal, $3 \%$ molasses, $1 \% \mathrm{CaCl}_{2}, 0.4 \% \mathrm{NaCl}$, a mixture of minerals (dicalcium phosphate, $45.8 \mathrm{mg}$; magnesium sulfate, $15 \mathrm{mg}$; manganese sulfate, $6.15 \mathrm{mg}$; ferric sulfate, 50 $\mathrm{mg}$; potassium iodide, $0.392 \mathrm{mg}$; copper sulfate, $5 \mathrm{mg}$; cobalt sulfate, $0.1 \mathrm{mg}$; and zinc sulfate, $5 \mathrm{mg} / \mathrm{kg}$ pellets) and vitamins (6,000 IU of vitamin A, $40 \mathrm{mg}$ of vitamin $\mathrm{E}, 6 \mathrm{mg}$ of vitamin $\mathrm{C}, 4 \mathrm{mg}$ of vitamin $\mathrm{B}_{2}, 3$ $\mathrm{mg}$ of folic acid, $0.05 \mathrm{mg}$ of niacin, $900 \mathrm{IU}$ of vitamin $\mathrm{D}_{3}, 2 \mathrm{mg}$ of vitamin $\mathrm{K}_{3}, 2 \mathrm{mg}$ of vitamin $\mathrm{B}_{1}, 2 \mathrm{mg}$ of vitamin $\mathrm{B}_{6}, 0.05 \mathrm{mg}$ of biotin, $10 \mathrm{mg}$ of calcium pantothenate $/ \mathrm{kg}$ of pellets), and $0.1 \%$ methionine. The chemical analysis of the pellets showed that they contained 17.5\% CP (method 988.05; AOAC, 1990), 14.0\% crude fiber (method 989.03; AOAC, 1990), 2.7\% crude fat, and 2,200 kcal/kg of diet (method 920.39; AOAC, 1990). Tap water was provided ad libitum and rats were acclimated for 2 wk at $25 \pm 1^{\circ} \mathrm{C}$ with a 12 -h dark and light cycle (Childs et al., 2002). The protein concentrate hydrolysates were evaluated by RP-HPLC and sensory evaluation to detect bitterness. Sample number 9 (Figure 3) was selected for use in animal treatments because it had low bitterness and good hydrolysis. For diabetic groups, rats were fasted for $12 \mathrm{~h}$ before alloxan injection and then injected with 1 dose of alloxan at $120 \mathrm{mg} / \mathrm{kg}$ of BW. The experimental period was $6 \mathrm{wk}$ after stabilization of diabetes for $1 \mathrm{wk}$ and the animals were divided into 6 major groups as follows. Group 1: 10 healthy rats (control); group 2: 10 diabetic rats
(control-D); group 3: 10 healthy rats that received an intragastric dose of milk protein concentrate at 800 $\mathrm{mg} / \mathrm{kg}$ of BW per day (MPC); group 4: 10 diabetic rats that received an intragastric dose of milk protein concentrate at $800 \mathrm{mg} / \mathrm{kg}$ of BW per day (MPC-D); group 5: 10 healthy rats that received an intragastric dose of milk protein concentrate hydrolysate at 800 $\mathrm{mg} / \mathrm{kg}$ of BW per day (MPCH); and group 6: 10 diabetic rats received an intragastric dose of milk protein concentrate hydrolysate at $800 \mathrm{mg} / \mathrm{kg}$ of $\mathrm{BW}$ per day (MPCH-D). At the end of the experimental period, rats were fasted for $12 \mathrm{~h}$, anesthetized with ether, and killed. Fasting blood samples were collected in heparinized tubes from the killed animals. Plasma was obtained by centrifugation of samples at $7,200 \times g$ at $4^{\circ} \mathrm{C}$ for 20 min (Sigma centrifuge 113, VWR International), and then the supernatant was stored at $-80^{\circ} \mathrm{C}$ until used for analyses (El-Demerdash et al., 2005).

\section{Antioxidant Parameters in Plasma and Liver}

TBARS Content. The TBARS content of the plasma and liver was assayed by the method of Tappel and Zalkin (1959). Two test tubes were prepared, one for the blank and other for the sample (plasma or liver tissue). In the sample tube, $1 \mathrm{~mL}$ of sample was added to $2 \mathrm{~mL}$ of $15 \%$ trichloroacetic acid (TCA), mixed well, and centrifuged at $1,000 \times g$ at $4^{\circ} \mathrm{C}$ for $20 \mathrm{~min}$. In another tube, $1 \mathrm{~mL}$ of $0.7 \%$ thiobarbituric acid was added to $2 \mathrm{~mL}$ of supernatant. The blank was prepared by adding $2 \mathrm{~mL}$ of TCA to $1 \mathrm{~mL}$ of thiobarbituric acid. The sample and blank test tubes were incubated for 20 min in water bath at boiling temperature and cooled; then, the absorbance was measured at $532 \mathrm{~nm}$. The TBARS content was measured as follows:

$$
\begin{aligned}
& \text { TBARS concentration in plasma }(\mathrm{nmol} / \mathrm{mL}) \\
& =\left(\operatorname{Abs} \times 10^{3}\right) / 156 ;
\end{aligned}
$$

TBARS concentration in liver (nmol / g of tissue)

$$
=\frac{\left(\mathrm{Abs} \times 10^{3}\right)}{156} \times 10 \text {, }
$$

where Abs = sample absorbance, $156=$ extension coefficient $\left(\mu M^{-1} \mathrm{~cm}^{-1}\right)$, and $10=$ dilution factor.

\section{Catalase Enzyme Activity in Plasma and Liver}

Catalase (CAT) enzyme activity in plasma and liver was determined according to method of Luck (1974). In a glass tube, $2.5 \mathrm{~mL}$ of $\mathrm{H}_{2} \mathrm{O}_{2}$ buffer $(80 \mu \mathrm{L}$ of $30 \%$ 
$\mathrm{H}_{2} \mathrm{O}_{2}$ was dissolved in $100 \mathrm{~mL}$ of sodium- potassium phosphate buffer, $0.15 \mathrm{M}$, pH 7) was added to $50 \mu \mathrm{L}$ of sample (plasma or liver) and mixed by vortex. The absorbance was measured after $30 \mathrm{~s}$ and then $90 \mathrm{~s}$ at $240 \mathrm{~nm}$ using a $3-\mathrm{mL}$ quartz cuvette; $2.5 \mathrm{~mL}$ of $\mathrm{H}_{2} \mathrm{O}_{2}$ buffer was used as the blank. The CAT activity was measured as follows:

Activity of $\mathrm{CAT}(\mathrm{U} / \mathrm{min}$ per $\mathrm{mL}$ of serum)

$$
=\frac{\Delta \mathrm{Abs}}{0.0008} \times 1 \mathrm{~min}
$$

Specific activity of CAT (U/min per mg of protein)

$$
=\frac{\Delta \mathrm{Abs}}{0.0008} \times 1 \mathrm{~min},
$$

where $\Delta \mathrm{Abs}$ is the difference in sample absorbance after 30 and $90 \mathrm{~s}$.

\section{Superoxide Dismutase Enzyme Activity in Plasma and Liver}

Superoxide dismutase (SOD) enzyme activity in plasma and liver was assayed by the method of Misra and Fridovich (1972). In the sample tube, $20 \mu \mathrm{L}$ of sample (plasma or liver tissues) was added to $960 \mu \mathrm{L}$ of sodium carbonate buffer (50 $\mathrm{mM}, \mathrm{pH} 10.2)$ and $0.1 \mathrm{mM}$ EDTA. The reaction was started by adding $20 \mu \mathrm{L}$ of 30 $\mathrm{m} M$ epinephrine (dissolved in $0.05 \% \mathrm{vol} / \mathrm{vol}$ acetic acid) to the mixture. The control tube was prepared like the sample tube except that $20 \mu \mathrm{L}$ of distilled water was used instead of the sample. The blank tube contained only $1,000 \mu \mathrm{L}$ of sodium carbonate buffer $(0.05 \mathrm{M}, \mathrm{pH}$ 10.2). The increase in optical density was measured at $480 \mathrm{~nm}$ for 4 min using a spectrophotometer and activity calculated as follows:

$$
\begin{aligned}
& \% \text { inhibition } \\
& =100-\left(\frac{\Delta \text { Abs control }-\Delta \text { Abs sample }}{\Delta \text { Abs control }} \times 100\right) ; \\
& \text { Activity }(\mathrm{U} / \mathrm{mL})=\% \text { inhibition } \times 3.75 ; \\
& \text { Specific activity }(\text { units } / \mathrm{mg} \text { of protein }) \\
& =\frac{\% \text { inhibition } \times 3.75 \times 10}{\mathrm{mg} \text { of protein }}
\end{aligned}
$$

where $\Delta \mathrm{Abs}$ control is the difference in control absorbance at different times and $\Delta \mathrm{Abs}$ sample is the difference in control absorbance at different times.

\section{Reduced Glutathione Concentration in Plasma and Liver}

Reduced GSH content in plasma and liver was assayed by the method of Jollow et al. (1974). Protein was precipitated in an ice-cold system as follows. For plasma, $100 \mu \mathrm{L}$ of plasma was added to $150 \mu \mathrm{L}$ of $4 \%$ sulfosalicylic acid (SSA) in a 5 -mL plastic test tube and centrifuged at $5,000 \times g$ at $4^{\circ} \mathrm{C}$ for $10 \mathrm{~min}$. For liver, $150 \mu \mathrm{L}$ of homogenate was added to $150 \mu \mathrm{L}$ of SSA in a 5 -mL plastic test tube and centrifuged at $5,000 \times g$ at $4^{\circ} \mathrm{C}$ for $10 \mathrm{~min}$.

The GSH concentration was determined as follows. In a 5 -mL glass tube, $66 \mu \mathrm{L}$ of supernatant was added to $66 \mu \mathrm{L}$ of $0.01 M$ 5,5-dithiobis-2-nitrobenzoic acid (DTNB) and $865 \mu \mathrm{L}$ of potassium phosphate buffer (0.1 M, pH 7.4). After 5 min, the absorbance was measured against SSA as blank at $412 \mathrm{~nm}$ and the concentration calculated as follows:

$$
\mathrm{GSH} \text { concentration }=\frac{\mathrm{Abs}}{0.416} \times 2 \mathrm{U} / \mathrm{mL} \text {; }
$$

GSH concentration $=\frac{\mathrm{Abs}}{0.049} \times 10 \mu \mathrm{mol} / \mathrm{g}$ of wet tissue

where Abs is the sample absorbance.

\section{Glutathione-S Transferase Activity in Plasma and Liver}

Glutathione-S-transferase (GST) activity was determined according to Habig et al. (1974). Seven hundred microliters of $0.1 M$ potassium phosphate buffer $(\mathrm{pH}$ 6.5), $50 \mu \mathrm{L}$ of reduced GSH, and $5 \mu \mathrm{L}$ of $1 \mathrm{~m} M p$ nitrobenzylchloride were added to $12.5 \mu \mathrm{L}$ of sample (plasma or liver tissue), mixed, and incubated at room temperature for $20 \mathrm{~min}$. The GST activity was measured spectrophotometrically at $310 \mathrm{~nm}$ against an air blank and the concentration calculated as follows:

GST activity in plasma $=\left(\frac{\mathrm{Abs}}{\Delta \varepsilon}\right) \times 3 \mu \mathrm{mol} / \mathrm{h}$;

GST specific activity in liver

$$
=\frac{\left[\left(\frac{\mathrm{Abs}}{\Delta \varepsilon}\right) \times 3\right]}{\mathrm{mg} \text { of protein }} \mu \mathrm{mol} / \mathrm{h} \text { per mg of protein, }
$$

where $\Delta \varepsilon$ (the difference in the molar extinction coefficient) $=1.9 \mathrm{mM}^{-1} \mathrm{~cm}^{-1}$. 


\section{Glutathione Peroxidase Activity in Plasma and Liver}

Glutathione peroxidase (GPX) activity in plasma and liver tissue was assayed by the methods of Chiu et al. (1976). In a test tube, $0.05 \mathrm{~mL}$ of sample (plasma or tissues) was added to $0.75 \mathrm{~mL}$ of $0.05 \mathrm{M}$ Tris $\mathrm{HCl}$ buffer, $\mathrm{pH}$ 7.6, $0.1 \mathrm{~mL}$ of reduced GSH, and $0.1 \mathrm{~mL}$ of cumene hydroperoxide, mixed, and incubated for 5 min at $37^{\circ} \mathrm{C}$. In another tube, $0.05 \mathrm{~mL}$ of supernatant was added to $0.75 \mathrm{~mL}$ of $0.05 M$ Tris $\mathrm{HCl}$ buffer, $\mathrm{pH}$ 7.6 , and $0.1 \mathrm{~mL}$ of reduced GSH, and then incubated for $5 \mathrm{~min}$ at $37^{\circ} \mathrm{C}$ as a control. Then, $0.1 \mathrm{~mL}$ of TCA $15 \%$ was added to both control and sample, and 0.1 $\mathrm{mL}$ of cumene hydroperoxide, $\mathrm{pH}$ 7.6, was added to the control only. Both tubes were incubated for $10 \mathrm{~min}$ at $37^{\circ} \mathrm{C}$ and centrifuged for $20 \mathrm{~min}$ at $1,000 \times \mathrm{g}$ at $4^{\circ} \mathrm{C}$. Then, $2 \mathrm{~mL}$ of $0.4 M$ Tris $\mathrm{HCl}$ buffer, $\mathrm{pH} 8.9$, and 0.1 $\mathrm{mL}$ of DTNB were added to $1 \mathrm{~mL}$ of supernatant for both sample and control. The optical density of the yellow color obtained was measured at $412 \mathrm{~nm}$ within 5 min and the concentration calculated as follows:

$$
\text { GPX activity }=\frac{\text { Abs control }- \text { Abs sample }}{0.0008 \times 3} \mathrm{U} / \mathrm{mL} \text {; }
$$

GPX specific enzyme activity

$$
=\frac{\mathrm{E} \times 6.2 \times 10 \times 10}{13.1 \times 0.05 \times 10} \times 25 \mathrm{IU} / \mathrm{g} \text { of wet tissue, }
$$

where Abs control $=$ the control absorbance, Abs sample $=$ the sample absorbance, $\mathrm{E}=$ the difference in absorbance between control and sample, $13.1 \mathrm{M}^{-1}$ $\mathrm{cm}^{-1}=$ the extinction coefficient of DTNB, $0.05 \mathrm{~mL}$ $=$ the volume of the sample, and $6.2=$ the extinction coefficient of cumene hydroperoxide.

\section{Liver Antioxidant Parameters}

Livers were immediately removed at the end of the experiment, weighed, and washed using chilled saline solution. Tissues were minced and homogenized in ice-cold sucrose $(10 \% \mathrm{wt} / \mathrm{vol})$ in a Potter-Elvehjem type homogenizer. The homogenate was centrifuged at $10,000 \times g$ for $20 \mathrm{~min}$ at $4^{\circ} \mathrm{C}$ (El-Demerdash et al., 2005). The resultant supernatant of liver was used to determine enzyme activities (GST, SOD, GPX, and CAT) and concentrations of GSH and TBARS according to the previous methods.

\section{Statistical Analysis}

Data were analyzed as a completely randomized design (Steel and Torrie, 1981) using the general linear model procedure of SAS Institute Inc. (1986). Means were statistically compared using the least significant difference test at a 0.05 significance level.

\section{RESULTS}

\section{RP-HPLC}

The RP-HPLC chromatograms of the soluble peptide extracts from milk protein concentrate hydrolyzed by trypsin $(2 \times, 4 \times$, and $8 \times)$ at $\mathrm{pH} 6.9$ or 7.5 at $40^{\circ} \mathrm{C}$ for 20 and $24 \mathrm{~h}$ are illustrated in Figures 1, 2, 3, and 4. In MPC hydrolyzed using $2 \times$ trypsin at $\mathrm{pH} 6.9$ for 20 $\mathrm{h}$, a high quantity of 4 fragments was seen at $230 \mathrm{~nm}$ with retention times (RT) of 24.4, 42.5, 48.3, and 50.2 min (Figure 1); the last 3 peaks were found at 200 $\mathrm{nm}$ at almost the same concentration. More peptides were observed at $200 \mathrm{~nm}$ than at $230 \mathrm{~nm}$. In MPC hydrolyzed using $4 \times$ trypsin at $\mathrm{pH} 6.9$ for $20 \mathrm{~h}$, more peptides, including 4 dominant peaks, were seen at 200 and $230 \mathrm{~nm}$ compared with when using $2 \times$ trypsin hydrolysate. Minor differences were observed between chromatograms of $4 \times$ and $8 \times$ trypsin as only some small peptides could be seen in hydrolysate of $8 \times$ trypsin separated at $230 \mathrm{~nm}$ compared with those observed from $4 \times$ trypsin hydrolysate.

In hydrolysate of MPC at $\mathrm{pH} 6.9$ for $24 \mathrm{~h}$ by $2 \times, 4 \times$, and $8 \times$ trypsin for $24 \mathrm{~h}$, more peptides were detected in chromatograms of $2 \times$ and $4 \times$ trypsin/ $24 \mathrm{~h}$ compared with that in chromatograms of $2 \times$ and $4 \times \operatorname{trypsin} / 20$ h. Minor differences between chromatograms of $8 \times$ trypsin $/ 20 \mathrm{~h}$ and $8 \times \operatorname{trypsin} / 24 \mathrm{~h}$ were observed. The RP-HPLC chromatogram of the $\mathrm{pH}$ 4.6-soluble peptide extracts from MPC hydrolyzed by trypsin at $\mathrm{pH} 7.5$ for 20 and $24 \mathrm{~h}$ are illustrated in Figures 3 and 4 . The RP-HPLC chromatograms showed that the trypsin produced a greater diversity of peptides after $24 \mathrm{~h}$ than after $20 \mathrm{~h}$ of incubation. The high quantities of 4 fragments that separated from hydrolysate at $\mathrm{pH} 6.8$ were also eluted at retention times of $24.4,42.5,48.3$, and 50.2 min in hydrolysate of $2 \times$ trypsin at $\mathrm{pH} 7.5$ for 20 $\mathrm{h}$ (Figure 3), with other smaller peptides in hydrolysate of $2 \times$ trypsin at $\mathrm{pH} 7.5$ compared with that at $\mathrm{pH} 6.8$. These fragments also appeared in MPC hydrolysates of $4 \times$ and $8 \times$ trypsin with higher relative concentrations than with $2 \times$ trypsin for the same incubation period and $\mathrm{pH}$ value.

\section{Antioxidant Enzymes in Plasma}

Data in Table 1 indicate that treatment with alloxan alone (to induce diabetes) significantly $(P<0.05)$ increased the levels of TBARS in plasma. The TBARS 
level was significantly $(P<0.05)$ lower in rats treated with oral intake of MPC and MPCH. No significant $(P$ $>0.05$ ) difference was found in TBARS levels among control rats and MPC, MPC-D, MPCH, and MPCH-D rats (i.e., rats treated orally with $\mathrm{MPC}$ and $\mathrm{MPCH}$ ). These results indicated that oral intake of MPC or $\mathrm{MPCH}$ reduced free radical levels in healthy and diabetic rats.

Table 1 shows results of CAT activity in blood plasma of healthy and diabetic rats and the effect of oral intake of MPC and MPCH on CAT activity. The lowest CAT activity was found in blood plasma of the control-D (diabetic control) group. Treatment with MPC and MPCH increased CAT activity in diabetic rats compared with the control-D group. Meanwhile, CAT activity was significantly $(P<0.05)$ increased in blood plasma of healthy (nondiabetic) rats treated with MPC and MPCH compared with control, and no significant $(P>0.05)$ difference was present between rats treated with MPC and MPCH.

Table 1 shows the results of SOD activity in blood plasma of healthy and diabetic rats and the effect of oral intake of MPC and MPCH. The results showed that SOD activity was significantly $(P<0.05)$ lower in the control-D group than in other groups. Meanwhile, no significant $(P>0.05)$ difference was present between control (healthy) and control-D (diabetic) groups. The SOD activities were significantly $(P<0.05)$ increased
1

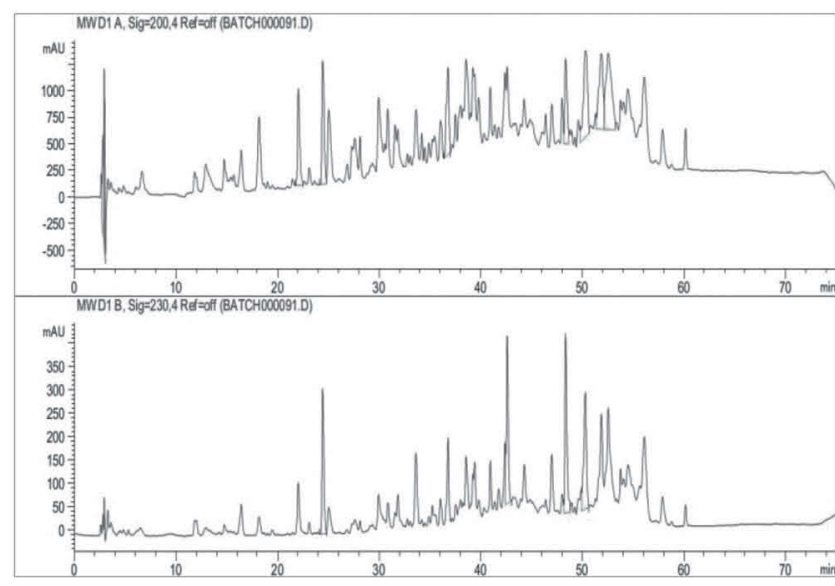

3

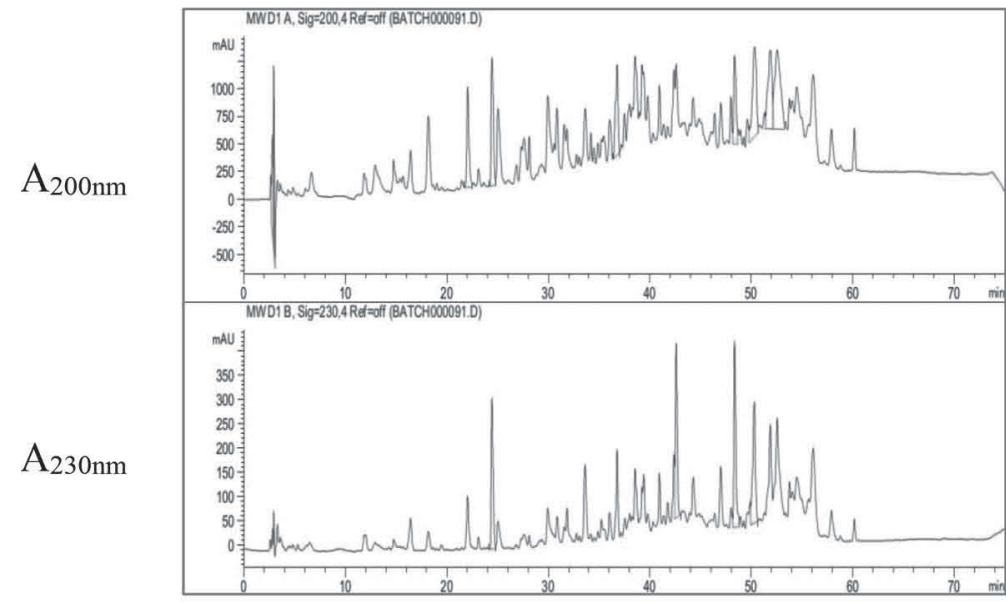

Retention time (min)

\section{2}

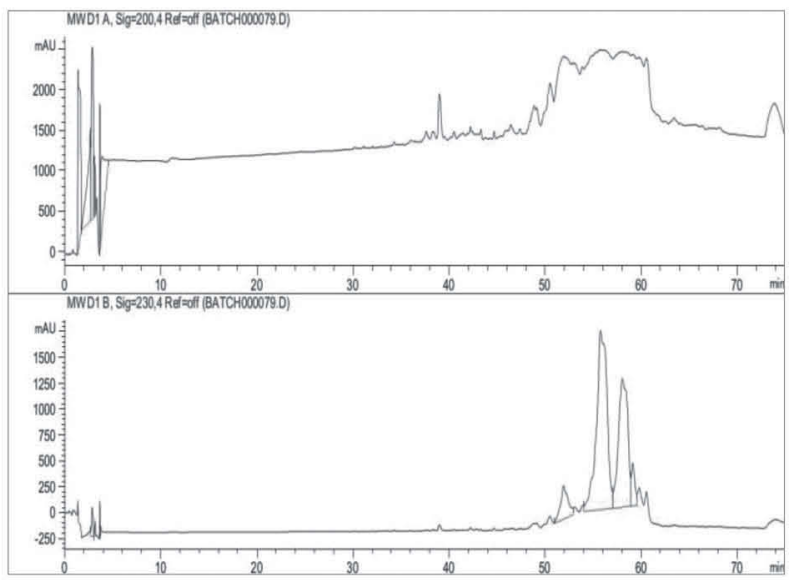

4

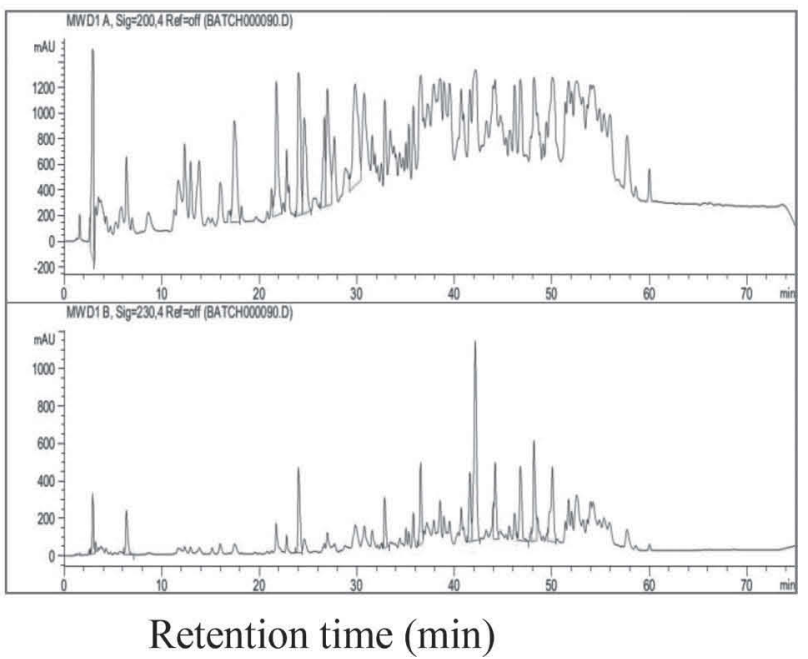

Figure 1. Reverse-phase HPLC pattern of (1) standard peptide mixture (H 2016, Sigma-Aldrich, St. Louis, MO), (2) milk protein concentrate (MPC), (3) milk protein concentrate hydrolysate (MPCH) sample no. 1 (treated by trypsin $2 \times$ at $\mathrm{pH} 6.9$ and $40^{\circ} \mathrm{C}$ for $20 \mathrm{~h}$ ), $(4) \mathrm{MPCH}$ sample no. 2 (treated by trypsin $4 \times$ at $\mathrm{pH} 6.9$ and $40^{\circ} \mathrm{C}$ for $20 \mathrm{~h}$ ). 


\section{2}
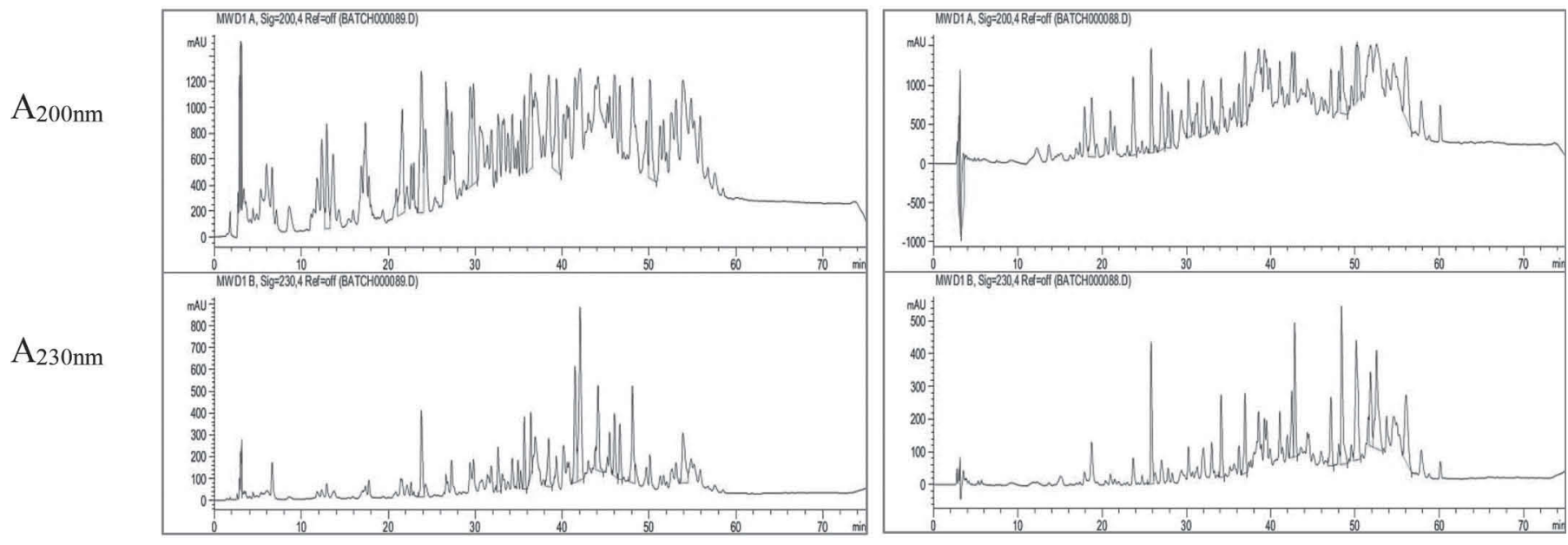

3

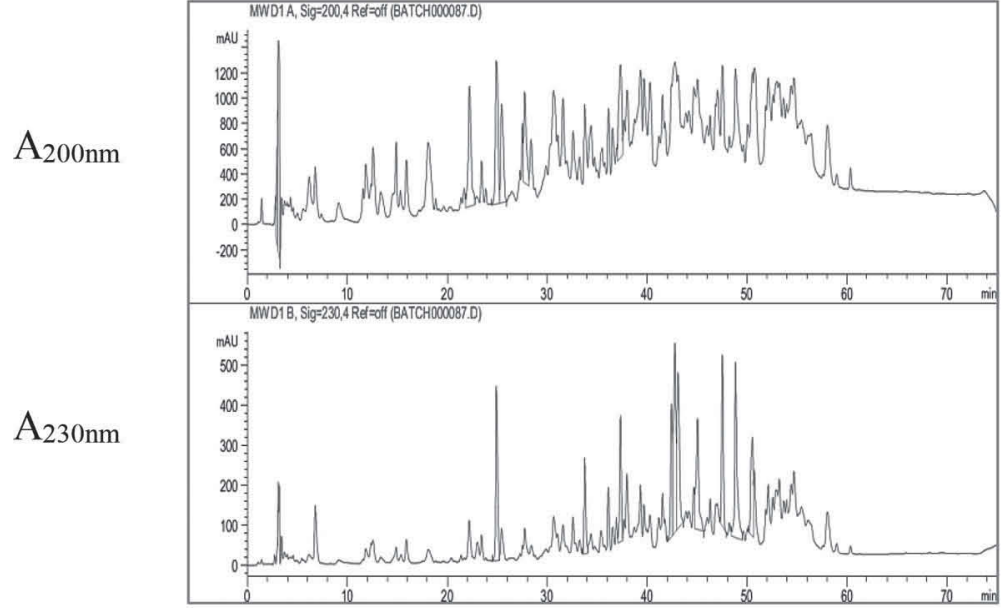

Retention time (min)
4

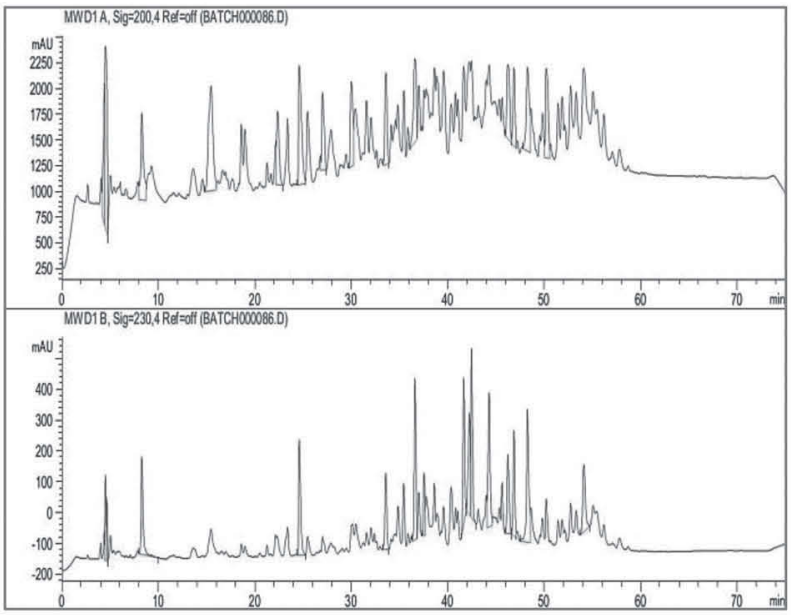

Retention time (min)

Figure 2. Reverse-phase HPLC pattern of (1) milk protein concentrate hydrolysate (MPCH) sample no. 3 (treated by trypsin $8 \times$ at pH 6.9 and $40^{\circ} \mathrm{C}$ for $20 \mathrm{~h}$ ), (2) MPCH sample no. 4 (treated by trypsin $2 \times$ at $\mathrm{pH} 6.9$ and $40^{\circ} \mathrm{C}$ for $24 \mathrm{~h}$ ), (3) MPCH sample no. 5 (treated by trypsin $4 \times$ at $\mathrm{pH} 6.9$ and $40^{\circ} \mathrm{C}$ for $24 \mathrm{~h}$ ), (4) $\mathrm{MPCH}$ sample no. 6 (treated by trypsin $8 \times$ at $\mathrm{pH} 6.9$ and $40^{\circ} \mathrm{C}$ for $24 \mathrm{~h}$ ).

in healthy rats treated with MPC and MPCH. The treatment of diabetic rats with MPCH significantly $(P$ $<0.05)$ increased SOD activity.

Results of GSH activity in blood plasma of healthy and diabetic rats and the effect of oral intake of MP and MPH are shown in Table 1. No significant differences were detected between GSH in plasma of control and control-D rats. Oral intake of MPC and MPCH significantly $(P<0.05)$ increased the level of GSH in blood of healthy and diabetic rats. However, treatment with MPCH significantly $(P<0.05)$ increased the level of GSH compared with treatment with MPC.
Table 1 shows the effect of oral intake of MPC and MPCH on GST activity in blood plasma of healthy and diabetic rats. No significant $(P>0.05)$ differences in GST activity were found among control, MPC, MPCH, MPC-D, and MPCH-D groups. Also, no significant $(P>0.05)$ difference was found between control and control-D groups.

Blood plasma of diabetic rats had a lower level of GPX activity compared with healthy rats on the same treatment (Table 1). Activity of GPX was increased when diabetic and healthy rats received MPC and MPCH. Meanwhile, GPX activity was significantly $(P$ 
1

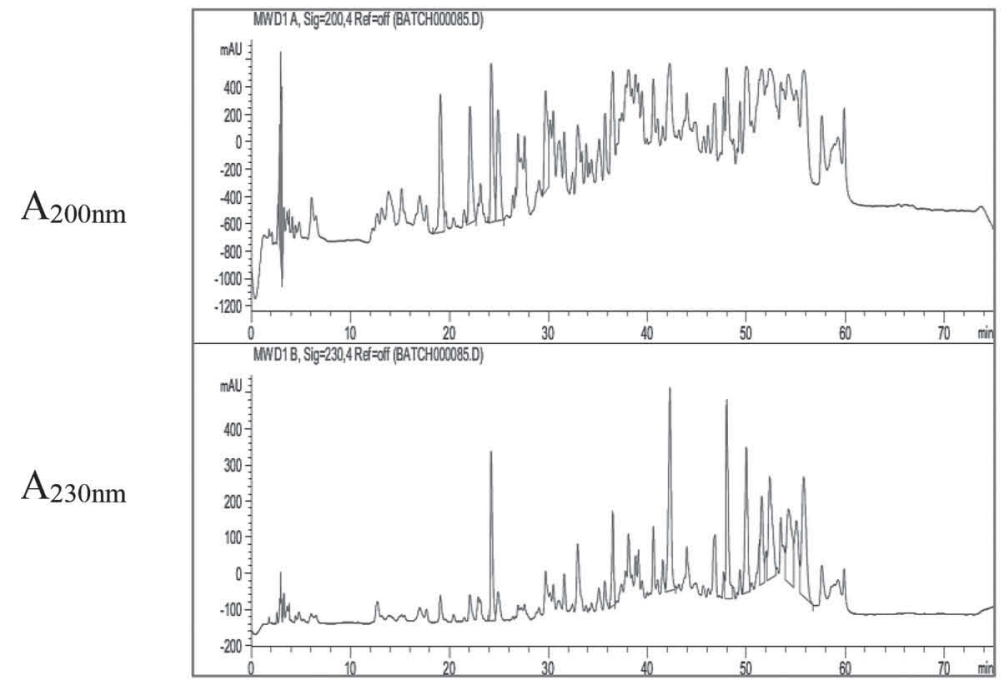

3

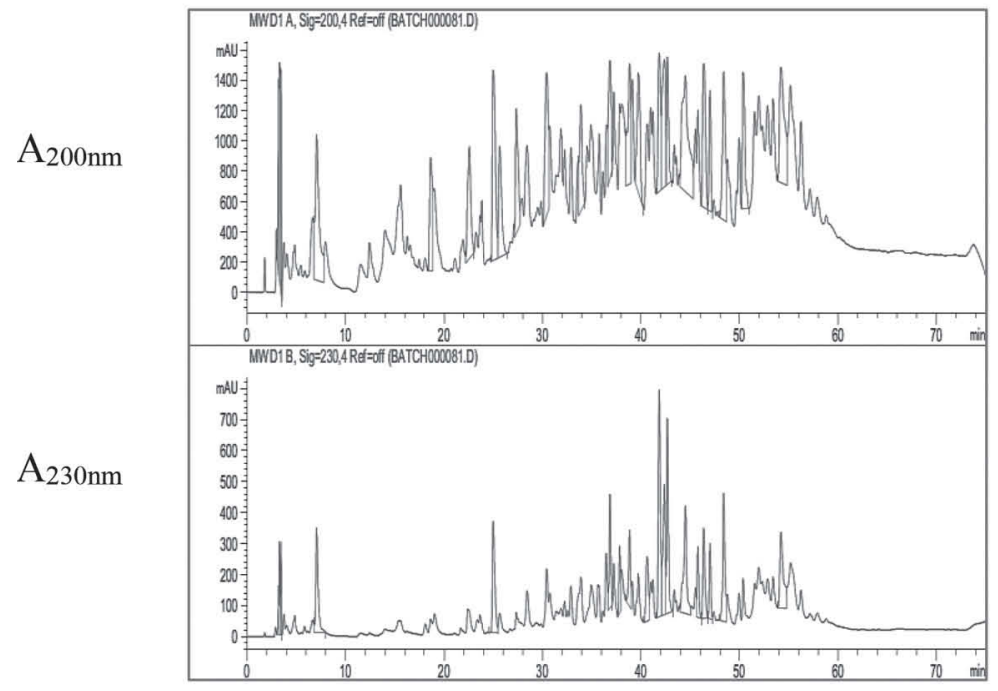

Retention time (min)
2

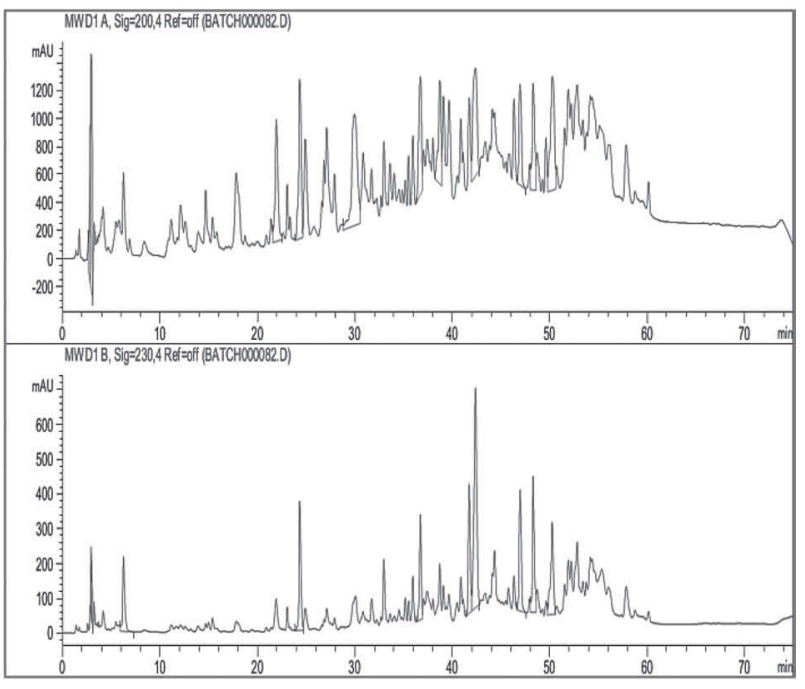

4

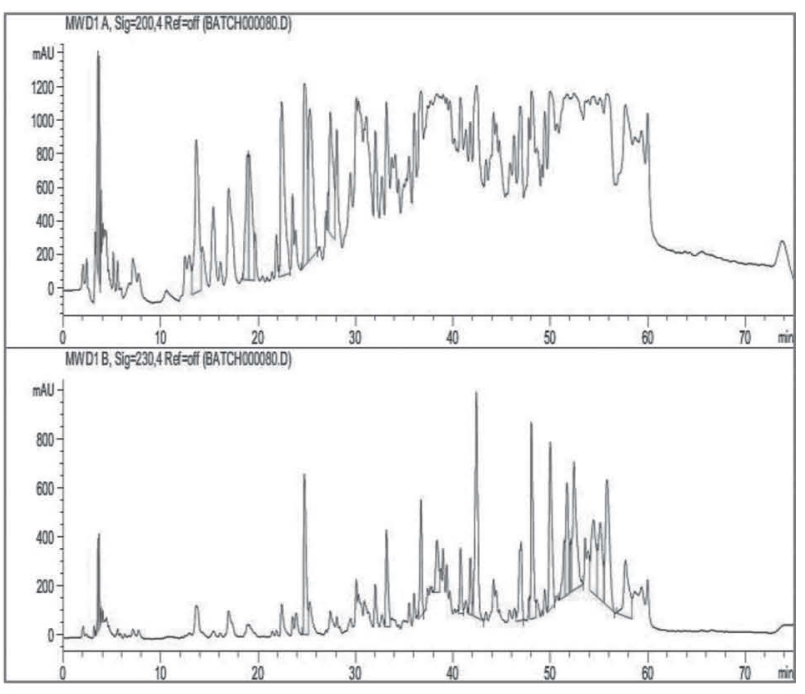

Retention time (min)

Figure 3. Reverse-phase HPLC pattern of (1) milk protein concentrate hydrolysate (MPCH) sample no. 7 (treated by trypsin $2 \times$ at pH 7.5 and $40^{\circ} \mathrm{C}$ for $20 \mathrm{~h}$ ), (2) $\mathrm{MPCH}$ sample no. 8 (treated by trypsin $4 \times$ at $\mathrm{pH} 7.5$ and $40^{\circ} \mathrm{C}$ for $20 \mathrm{~h}$ ), (3) MPCH sample no. 9 (treated by trypsin $8 \times$ at $\mathrm{pH} 7.5$ and $40^{\circ} \mathrm{C}$ for $20 \mathrm{~h}$ ), (4) $\mathrm{MPCH}$ sample no. 10 (treated by trypsin $2 \times$ at $\mathrm{pH} 7.5$ and $40^{\circ} \mathrm{C}$ for $24 \mathrm{~h}$ ).

$<0.05)$ increased in plasma of MPC and MPC-D rats compared with all other treated groups.

\section{Antioxidant Enzymes in Liver}

Levels of TBARS in liver tissue were higher in diabetic rats compared with healthy rats (Table 2). Levels of TBARS decreased in diabetic and healthy rats treated with MPC or MPCH; the decrease in TBARS activity was nonsignificant $(P>0.05)$ in healthy rats treated with MPC and significant $(P<0.05)$ in healthy rats treated with $\mathrm{MPCH}$. These results confirmed that the MPCH was good source of free radical scavenging and significantly improved the health of diabetic rats.

No significant $(P>0.05)$ differences were found between healthy and diabetic control groups in CAT activity of liver tissue (Table 2). Intake of MPC and MPCH significantly $(P<0.05)$ increased CAT activity 
Table 1. Changes in levels of plasma thiobarbituric acid reactive substances (TBARS) glutathione (GSH), and activities of glutathione peroxidase (GPX), glutathione S-transferase (GST), catalase (CAT), and superoxide dismutase (SOD) in male diabetic (D) and nondiabetic rats treated with milk protein concentrate $(\mathrm{MPC})$ or milk protein concentrate hydrolysate $(\mathrm{MPCH})^{1}$

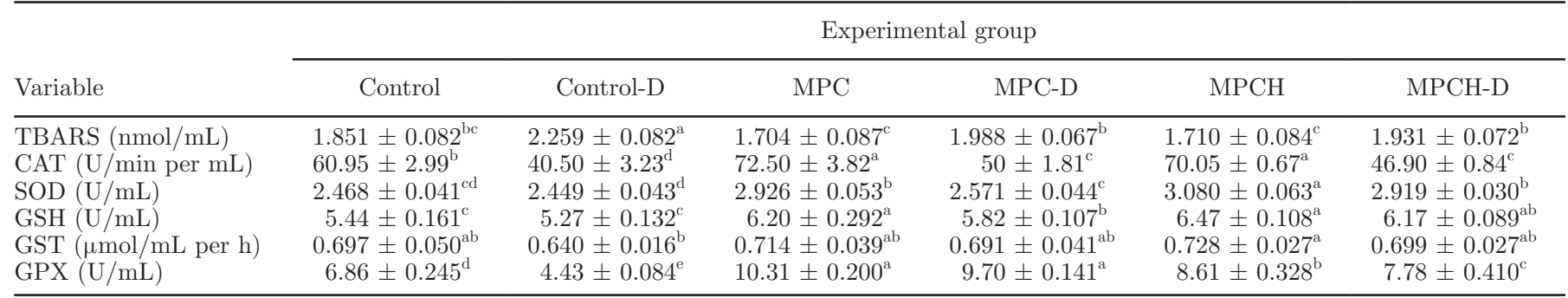

${ }^{\mathrm{a} e}$ Mean values within a row not sharing common superscript letters were significantly different, $P<0.05$.

${ }^{1}$ Values are expressed as means $\pm \mathrm{SE} ; \mathrm{n}=7$ for each treatment group.

(U/min per mg of protein) in liver tissue of diabetic and healthy rats. In contrast, oral intake of MPC significantly $(P<0.05)$ increased CAT activity in liver tissue of diabetic and healthy rats (MPC-D and MPC groups) compared with all other treated groups.

The activity of SOD was significantly higher $(P<$ 0.05 ) in healthy rats (control, MPC, and MPCH) than in diabetic rats (control-D, MPC-D, and MPCH-D; Table 2). Oral intake of MPCH decreased significantly $(P<0.05)$ SOD activity in healthy and diabetic rats, whereas oral intake of MPC had no significant $(P>$ 0.05 ) effect on SOD activity in healthy rats but improved SOD activity in diabetic rats compared with corresponding controls.

Treatment with alloxan alone (control-D) significantly $(P<0.05)$ decreased GSH activity in liver compared with the control group (control; Table 2). Meanwhile, oral intake of MPCH significantly increased $(P<0.05)$ GSH level in healthy rats and returned the level of GSH in diabetic rats to the control value. No significant difference $(P>0.05)$ was found between MPCH-D and the healthy control group. The data in Table 2 show no significant differences $(P>0.05)$ among controls and treated groups for liver GST activity.

Oral intake of MPC and MPCH significantly increased $(P<0.05)$ GPX activity in liver tissue of healthy and diabetic rats compared with controls (Table 2). Oral intake of MPCH significantly increased $(P<0.05)$ GPX activity in healthy and diabetic rats compared with intake of MPC. Meanwhile, no significant difference $(P$ $>0.05)$ was found in GPX activity between MPC and MPC-D rats.
2

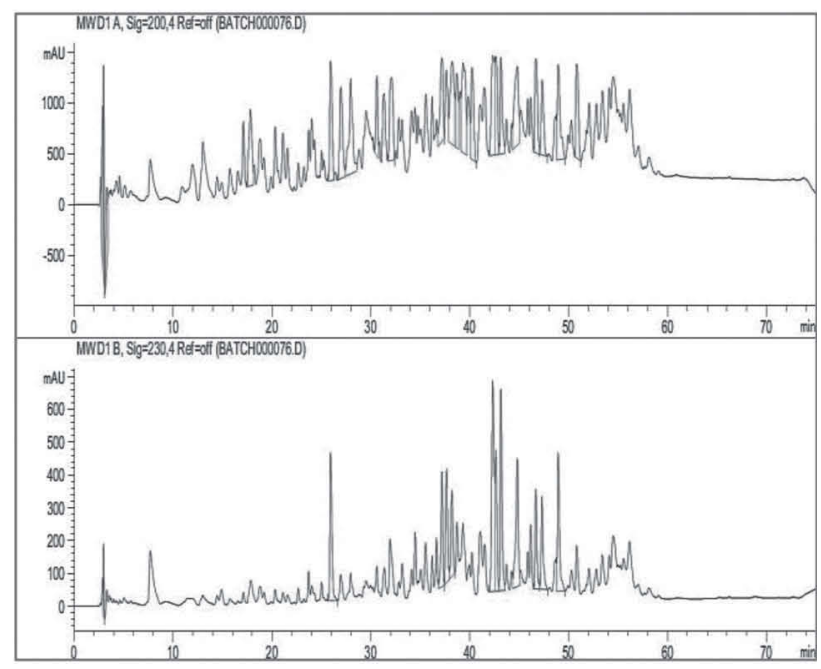

Retention time ( $\mathrm{min})$

Figure 4. Reverse-phase HPLC pattern of (1) milk protein concentrate hydrolysate (MPCH) sample no. 11 (treated by trypsin $4 \times$ at $\mathrm{pH} 7.5$ and $40^{\circ} \mathrm{C}$ for $24 \mathrm{~h}$ ), (2) $\mathrm{MPCH}$ sample no. 12 (treated by trypsin $8 \times$ at $\mathrm{pH} 7.5$ and $40^{\circ} \mathrm{C}$ for $24 \mathrm{~h}$ ). 
Table 2. Changes in levels of liver thiobarbituric acid reactive substance (TBARS) and glutathione (GSH) and activities of glutathione peroxidase (GPX), glutathione S-transferase (GST), catalase (CAT), and superoxide dismutase (SOD) in male diabetic (D) and nondiabetic rats treated with milk protein concentrate $(\mathrm{MPC})$ and milk protein concentrate hydrolysate $(\mathrm{MPCH})^{1}$

\begin{tabular}{|c|c|c|c|c|c|c|}
\hline Variable & \multicolumn{6}{|c|}{ Experimental group } \\
\hline TBARS & $30.32 \pm 2.375^{\mathrm{c}}$ & $42.56 \pm 1.469^{\mathrm{a}}$ & $29.86 \pm 0.887^{\mathrm{c}}$ & $33.65 \pm 0.317^{\mathrm{b}}$ & $21.67 \pm 0.679^{\mathrm{d}}$ & $29.24 \pm 0.481^{\mathrm{c}}$ \\
\hline $\mathrm{SOD}(\mathrm{U} / \mathrm{mg}$ of protein) & $1.520 \pm 0.039^{\mathrm{a}}$ & $1.349 \pm 0.013^{\mathrm{cd}}$ & $1.513 \pm 0.052^{\mathrm{a}}$ & $1.433 \pm 0.011^{\mathrm{b}}$ & $1.399 \pm 0.011^{\mathrm{bc}}$ & $1.304 \pm 0.023^{\mathrm{d}}$ \\
\hline GSH ( $\mu \mathrm{mol} / \mathrm{g}$ of tissue) & $5.402 \pm 0.217^{\mathrm{ab}}$ & $5.041 \pm 0.035^{\mathrm{c}}$ & $5.36 \pm 0.118^{\mathrm{abc}}$ & $5.286 \pm 0.083^{\mathrm{bc}}$ & $5.710 \pm 0.074^{\mathrm{a}}$ & $5.429 \pm 0.230^{\mathrm{ab}}$ \\
\hline GST $(\mu \mathrm{mol} / \mathrm{h}$ per $\mathrm{mg}$ of protein $)$ & $0.948 \pm 0.023^{\mathrm{a}}$ & $0.927 \pm 0.013^{\mathrm{a}}$ & $0.959 \pm 0.027^{\mathrm{a}}$ & $0.926 \pm 0.012^{\mathrm{a}}$ & $0.952 \pm 0.009^{\mathrm{a}}$ & $0.946 \pm 0.018^{\mathrm{a}}$ \\
\hline
\end{tabular}

${ }^{\mathrm{a}-\mathrm{d}}$ Mean values within a row not sharing common superscript letters were significantly different, $P<0.05$.

${ }^{1}$ Values are expressed as means $\pm \mathrm{SE} ; \mathrm{n}=6$ for each treatment group.

\section{DISCUSSION}

Diabetes is associated with an increase in oxidative stress as shown by an increase in serum malondialdehyde, and decreased levels of CAT, SOD, and GSH. In addition, diabetes is associated with an increase in total serum cholesterol triglyceride levels and a decrease in insulin and c-peptide levels (Moree et al., 2013). Free radicals may play a pivotal role in the pathogenesis of several diseases, including diabetes mellitus (FeilletCoudray et al., 1999).

Diabetes is a prevalent systemic disease affecting a significant proportion of the population worldwide. Oxidative stress is believed to play an important role, albeit not fully recognized, in the development of vascular complications in diabetes mellitus. Free radicalmediated oxidative damage has been observed in the development of both type I and type II diabetes mellitus (Marjani, 2010). Our results showed a significant increase in TBARS in control diabetic sera and liver tissue compared with other treated groups. Meanwhile, oral intake of MPC or MPCH reduced the TBARS level in both healthy and diabetic rats. These results were in agreement with Siva et al. (2012), who showed a significant decline in FRAP in type I and type II diabetic conditions compared with healthy individuals. This observation emphasizes the critical importance of maintaining the $\mathrm{AO}$ potential of the pancreatic $\beta$-cell to ensure both its survival and insulin secretion capacity during times of increased oxidative stress.

Jin et al. (2008) reported that TBARS levels are elevated and activities of AO enzymes (SOD, GPX, and CAT) are significantly reduced in streptozotocininduced diabetic rats. In the present study, activities of CAT, SOD, GSH, GST, and GPX were significantly decreased in blood plasma or liver tissue of control diabetic rats, whereas oral intake of MPC or MPCH increased the activity of these enzymes in healthy and diabetic rats. A greater increase in CAT activity was found in MPC and MPCH groups compared with MPC-D and MPCH-D groups in sera, but MPC and MPC-D groups had higher CAT activity than MPCH and MPCH-D groups in liver tissue. The MPCH and MPCH-D groups showed an increase in SOD activity in blood sera compared with healthy and diabetic groups, but MPC and MPC-D groups had significantly higher SOD than MPCH and MPCH-D groups in liver tissue. For GSH and GST, oral intake of MPC or MPCH significantly increased activities in blood sera and liver tissue of healthy and diabetic groups. In addition, GPX activity was significantly increased with groups with oral intake of MPC or MPCH.

Laakso (1984) reported that milk casein inhibits lipoxygenase-catalyzed lipid autoxidation. Quenching of free radicals by oxidation of AA residues in casein was proposed as the explanation. However, free AA could not substitute for casein as the $\mathrm{AO}$, suggesting that the primary structure of casein molecules played a role. Caseins have polar domains that contain phosphorylated serine residues, and their characteristic sequences, SerP-SerP-SerP-Glu-Glu, are effective cation chelators that form complexes with calcium, iron, and zinc. Thus, phosphorylated caseins, their peptides in the aqueous phase, or both could be a source of natural chelators to control lipid oxidation in food emulsions by binding and partitioning transition metals away from the emulsion droplet. Casein hydrolysates have been shown to be more effective inhibitors of lipid oxidation than the enriched CPP at equal phosphorus contents. Therefore, the AO properties might not be attributed solely to chelating of metals by phosphoseryl residues but also to scavenging of free radicals (Diaz et al., 2003).

In addition, AO activity of milk whey has been suggested. Such activity would include chelation of transition metals by serum albumin and lactoferrin, an ironbinding glycoprotein, as well as free radical scavenging activity by AA such as tyrosine and cysteine (Colbert and Decker, 1991). Hernández-Ledesma et al. (2005) 
identified several peptides in the $\beta$-LG A hydrolysate by pancreatin from the porcine pancreas (Corolase PP). One of the peptides, Trp-Tyr-Ser-Leu-Ala-MetAla-Ala-Ser-Asp-Ile, possessed higher radical scavenging activity than butylated hydroxyanisole.

Kamau et al. (2010) reported that peptides generated from the digestion of milk proteins have AO activity. These peptides are composed of 5 to $11 \mathrm{AA}$, including hydrophobic AA, proline, histidine, tyrosine, or tryptophan. Casein hydrolysates were reported to have higher concentrations of histidine, lysine, proline, and tyrosine than CPP, and all of these AA have been previously found to act as free radical scavengers (Pihlanto, 2006). Enriched CPP, casein hydrolysates, and low-molecularweight casein hydrolysates have been shown to inhibit TBARS formation in cooked ground beef. The ability to inhibit TBARS formation was highest with enriched $\mathrm{CPP}$, even though the hydrolysates had better AO activity.

Phelan et al. (2009) found that casein hydrolysates affected both cellular CAT activity and GSH content in Jurkat cells. In addition, they found that casein hydrolysates contained a certain degree of electron donating capacity as determined by the FRAP assay (17-32 mmol L ${ }^{-1}$ ). Mao et al. (2011) determined free-radicalscavenging activities of yak casein and its enzymatic hydrolysate toward DPPH, superoxide, and hydrogen peroxide. Yak casein hydrolysate prepared with alcalase had a more significant effect on attenuating free radicals of $\mathrm{DPPH}$, superoxide, and hydrogen peroxide.

Pritchard et al. (2010) found that the bioactive peptides in commercial Cheddar cheese showed the highest inhibition of DPPH. In addition, hydrolysates of whey protein isolate have been shown to possess $\mathrm{AO}$ activity. Digestion for $5 \mathrm{~h}$ with alcalase produced a hydrolysate with strong reducing power by FRAP assay. When whey protein isolate was fractionated based on molecular mass, the low-molecular-weight fraction (0.1-2.8 $\mathrm{kDa}$ ) was most potent (Peng et al., 2009). Ebaid et al. (2011) found that whey protein intake $(100 \mathrm{mg} /$ $\mathrm{kg}$ for $15 \mathrm{~d}$ pre- and post-injury) increased tissue GSH levels and reduced oxidative stress in these animals as it decreased tissue reactive oxygen species.

\section{CONCLUSIONS}

The results of the present study demonstrate that treating alloxan-induced diabetic rats with $\mathrm{MPCH}$ and MPC as antioxidant agents showed positive effects due to their ability to attenuate the reactivity of reactive oxygen species and to enhance activities of enzymes such as CAT, SOD, GSH, GST, and GPX, thereby preventing lipid peroxidation reactions. The present data showed that MPCH and MPC could be used as hypoglycemic agents due to their potency as antioxidants.

\section{ACKNOWLEDGMENTS}

This work was financially supported by Faculty of Agriculture, Alexandria University, Egypt.

\section{REFERENCES}

AOAC. 1990. Official Methods of Analysis of the Association of Official Analytical Agricultural Chemists, 13th ed. AOAC, Washington, DC.

Awad, S., Q. Q. Lüthi-Peng, and Z. Puhan. 1998. Proteolytic activities of Chymosin and porcine pepsin on buffalo, cow, and goat whole and $\beta$-casein fractions. J. Agric. Food Chem. 46:4997-5007.

Childs, A. C., S. L. Phaneuf, A. J. Dirks, T. Phillips, and C. Leeuwenburgh. 2002. Doxorubicin treatment in vivo causes cytochrome $\mathrm{C}$ release and cardiomyocyte apoptosis, as well as increased mitochondrial efficiency, superoxide dismutase activity, and Bcl-2:Bax ratio. Cancer Res. 62:4592-4598.

Chiu, D. T. Y., F. H. Stults, and A. L. Tappel. 1976. Purification and properties of rat lung soluble glutathione peroxidase. Biochim. Biophys. Acta 445:558-566.

Colbert, L. B., and E. A. Decker. 1991. Antioxidant activity of an ultrafiltration permeate from acid whey. J. Food Sci. 56:1249-1250.

Diaz, M., C. M. Dunn, D. J. McClements, and E. A. Decker. 2003. Use of caseinophosphopeptides as natural antioxidants in oil-in-water emulsions. J. Agric. Food Chem. 51:2365-2370.

Ebaid, H., A. Salem, A. Sayed, and A. Metwalli. 2011. Whey protein enhances normal inflammatory responses during cutaneous wound healing in diabetic rats. Lipids Health Dis. 10:235-245.

El-Demerdash, F. M., M. I. Yousef, and N. I. Abou El-Naga. 2005. Biochemical study on the hypoglycemic effects of onion and garlic in alloxan-induced diabetic rats. Food Chem. Toxicol. 43:57-63.

Feillet-Coudray, C., E. Rock, C. Coudray, K. Grzelkowska, V. Azaisraesco, D. Dardevet, and A. Mazur. 1999. Lipid peroxidation and antioxidant status in experimental diabetes. Clin. Chim. Acta. 284:31-43.

FitzGerald, R. J., B. A. Murray, and D. J. Walsh. 2004. Hypotensive peptides from milk proteins. J. Nutr. 134:980S-988S.

Gad, A., Y. Khadrawy, A. A. El-Nekeety, S. R. Mohamed, N. S. Hassan, and M. A. Abdel-Wahhab. 2011. Antioxidant activity and hepatoprotective effects of whey protein and spirulina in rats. Nutrition 27:582-589.

Gobbetti, M., F. Minervini, and C. G. Rizzello. 2004. Angiotensin I-converting enzyme-inhibitory and antimicrobial bioactive peptides. Int. J. Dairy Technol. 57:172-188.

Habig, W. H., M. J. Pabst, and W. B. Jakoby. 1974. Glutathione S transferases. The first enzymatic step in mercapturic acid formation. J. Biol. Chem. 249:7130-7139.

Hernández-Ledesma, B., A. Dàvalos, B. Bartolome, and L. Amigo. 2005. Preparation of antioxidant enzymatic hydrolysates from $\alpha$-lactalbumin and $\beta$-lactoglobulin. Identification of active peptides by HPLC-MS/MS. J. Agric. Food Chem. 53:588-593.

Jin, L., H. Y. Xue, L. J. Jin, S. Y. Li, and Y. P. Xu. 2008. Antioxidant and pancreas-protective effect of aucubin on rats with streptozotocin-induced diabetes. Eur. J. Pharmacol. 582:162-167.

Jollow, D. J., J. R. Mitchell, N. Zampaglione, and J. R. Gillete. 1974. Bromobenzene-induced liver necrosis, protective role of Glutathione and evidence for 3,4-bromobenzene oxide in the hepatotoxic metabolite. Pharmacology 11:151-169.

Kamau, S. M., R. R. Lu, W. Chen, X. M. Liu, F. W. Tian, Y. Shen, and T. Gao. 2010. Functional significance of bioactive peptides derived from milk proteins. Food Rev. Int. 26:386-401.

Kim, G. N., H. D. Jang, and C. I. Kim. 2007. Antioxidant capacity of caseinophosphopeptides prepared from sodium caseinate using alcalase. Food Chem. 104:1359-1365. 
Kitts, D. 2005. Antioxidant properties of casein-phosphopeptides. Trends Food Sci. Technol. 16:549-554.

Kitts, D. D., and K. Weiler. 2003. Bioactive proteins and peptides from food sources. Applications of bioprocesses used in isolation and recovery. Curr. Pharm. Des. 9:1309-1323.

Korhonen, H., and A. Pihlanto. 2006. Bioactive peptides: Production and functionality. Int. Dairy J. 16:945-960.

Laakso, S. 1984. Inhibition of lipid peroxidation by casein. Evidence of molecular encapsulation of 4,4-pentadiene fatty acids. Biochim. Biophys. Acta 792:11-15.

Luck, H. 1974. Catalase. Pages 885-895 in Method of Enzymatic Analysis. M. V. Bergmayer, ed. Verlag Chemic. Academic Press, New York, NY.

Mansour, H. A., A. S. Newairy, M. I. Yousef, and S. A. Sheweita. 2002. Biochemical study on the effects of some Egyptian herbs in alloxan-induced diabetic rats. Toxicology 170:221-228.

Mao, X., X. Cheng, X. Wang, and S. Wu. 2011. Free-radical- scavenging and anti-inflammatory effect of yak milk casein before and after enzymatic hydrolysis. Food Chem. 126:484-490.

Marjani, A. 2010. Lipid peroxidation alterations in type 2 diabetic patients. Pak. J Biol. Sci. 13:723-730.

Meisel, H., and R. J. FitzGerald. 2003. Biofunctional peptides from milk proteins: Mineral binding and cytomodulatory effects. Curr. Pharm. Des. 9:1289-1295.

Misra, H. P., and I. Fridovich. 1972. The role of superoxide anion in the autoxidation of epinephrine and a simple assay for superoxide dismutase. J. Biol. Chem. 247:3170-3175.

Moree, S. S., G. B. Kavishankar, and J. Rajesha. 2013. Antidiabetic effect of secoisolariciresinol diglucoside in streptozotocin-induced diabetic rats. Phytomedicine 20:237-245.

Otte, J., S. M. Shalaby, M. Zakora, A. H. Pripp, and S. A. El-Shabrawy. 2007. Angiotensin-converting enzyme inhibitory activity of milk protein hydrolysates: Effect of substrate, enzyme and time of hydrolysis. Int. Dairy J. 17:488-503.

Peng, X., Y. Xiong, and B. Kong. 2009. Antioxidant activity of peptide fractions from whey protein hydrolysates as measured by electron spin resonance. Food Chem. 113:196-201.

Phelan, M., S. A. Aherne-Bruce, D. O'Sullivan, R. J. FitzGerald, and N. M. O'Brien. 2009. Potential bioactive effects of casein hydrolysates on human cultured cells. Int. Dairy J. 19:279-285.
Picariello, G., P. Ferranti, O. Fierroa, G. Mamonea, S. Cairaa, A. Di Luccia, S. Monica, and F. Addeon. 2010. Peptides surviving the simulated gastrointestinal digestion of milk proteins: Biological and toxicological implications. J. Chromatogr. B Analyt. Technol. Biomed. Life Sci. 878:295-308.

Pihlanto, A. 2006. Antioxidative peptides derived from milk proteins. Int. Dairy J. 16:1306-1314.

Plaisancié, P., J. Claustrec, M. Estiennea, G. Henryd, R. Boutroud, A. Paqueta, and J. Léonild. 2013. A novel bioactive peptide from yoghurts modulates expression of the gel-forming MUC2 mucin as well as population of goblet cells and Paneth cells along the small intestin. J. Nutr. Biochem. 24:213-221.

Pritchard, S. R., M. Phillips, and K. Kailasapathy. 2010. Identification of bioactive peptides in commercial Cheddar cheese. Food Res. Int 43:1545-1548.

Sarmadi, B. H., and A. Ismail. 2010. Antioxidative peptides from food proteins. Peptides 31:1949-1956.

SAS Institute Inc. 1986. SAS User's Guide: Statistics, Version 5 ed. SAS Inst. Inc., Cary, NC.

Sheweita, S. A., A. A. Newairy, H. A. Mansour, and M. I. Yousef 2002. Effect of some hypoglycemic herbs on the activity of phase I and II drug-metabolizing enzymes in alloxan-induced diabetic rats. Toxicology 174:131-139.

Siva, L., S. V. Mythili, J. Rani, and P. S. Kumar. 2012. Biochemical and haematological aberrations in type I and type II diabetic patients in South India-A comparative study. Int. J. Res. Pharm. Biomed. Sci. 3:967-977.

Steel, R. G. D., and J. H. Torrie. 1981. Principles and Procedures of Statistics. A Biometrical Approach, 2nd ed. McGraw-Hill Book Company, New York, NY.

Szwajkowska, M., A. Wolanciuk, J. Barłowska, J. Król, and Z. Litwińczuk. 2011. Bovine milk proteins as the source of bioactive peptides influencing the consumers' immune system-A review. Anim. Sci. Pap. Rep. 29:269-280.

Tappel, A. L., and H. Zalkin. 1959. Inhibition of lipid peroxidation in mitochondria by vitamin E. Arch. Biochem. Biophys. 80:333-336.

Vermeirssen, V., J. VanCamp, and W. Verstraete. 2004. Bioavailability of angiotensin I-converting enzyme inhibitory peptides. Br. J. Nutr. 92:357-366. 